\title{
Beyond the Boundaries of Kochi: a Study of Raja Veera Keralavarma's Travel Narrative to Kashi
}

\author{
Niveditha Kalarikkal \\ Centre for Comparative Literature and Translation Studies, Central University of Gujarat, \\ Gandhinagar. kunjikavu@gmail.com
}

\begin{abstract}
Pilgrim narratives constitute a significant number of travel narratives which appeared in Sanskrit, English and various Indian bhashas in the $18^{\text {th }}$ and $19^{\text {th }}$ centuries. Raja Veera Kerala Varma IV, who ruled the erstwhile princely state of Kochi (Cochin) in South Western India, wrote an account of his pilgrimage to Kashi (Benares) during the years 1852-53. This travelogue in English was later translated into Malayalam by M. Raman Namboothiri and was published as Kochirajavinte Kashiyatra (The Cochin Raja's travel to Kashi) in 2013. The 'travel notes of the Raja of Kochi' which was available in the form of his personal journal describes his meetings with many British officials and common people on the way, in addition to sketching the varied geographies and religious places that he visited during the 220 days long pilgrimage. The Raja who started his pilgrimage from Trippunithura was accompanied by a royal retinue which included his tour manager, a white medical doctor named Bingle and a few other servants. Veera Kerala Varma, later referred to as the 'Maharaja who passed away in Kashi' had an untimely death due to smallpox and his travel narrative reached Kochi along with his physical remains. This paper attempts to do a close reading of the travelogue to reveal the inquisitiveness of a Raja who had close associations with the British administrators, as one who attempted to step out of the boundaries of his kingdom with an ethnographic intent. The description of people and their cultural practices that were different from his own 'country' can also throw light on how a member of the $19^{\text {th }} \mathrm{C}$ English educated Indian elites looked upon newly evolving territorial identities, scientific advancements and public institutions that were being established through colonization.
\end{abstract}

Keywords: pilgrim narrative, cultural boundaries, writing home, territorial identities, colonialism and technology, modern self

\section{Travel, Travelogue and the Travelling Subject}

Travel writing as a genre elucidates the experiences of a travelling subject who is away from one's homeland irrespective of the purpose behind his/her journey or the nature of the travel that is undertaken. A wide variety of narratives that fall under this genre in the modern times include the $\log$ books and personal accounts about their voyages written by $18^{\text {th }}$ century explorers and traveller-scientists like James Cook and Alexander Von Humboldt (Smethurst, 2012) to travel books like the Area of Darkness (1964) which was written by V.S. Naipaul based on the experiences of his travel to his ancestral land, India. The works that fall under this category range from "the most non fictional and referentialized texts" characterized by "authenticating dates and place names" to "the most idiosyncratically personalized" and "fantastically imaginative" (Van Den Abbeele, 1985, p. 5) ones written about a place and its people. Travelogues have been increasingly treated as products of cultural transactions which also reveal various power relations

(c) AesthetixMS 2020. This Open Access article is published under a Creative Commons Attribution Non-Commercial 4.o International License (http://creativecommons.org/licenses/by-nc/4.o/), which permits non-commercial re-use, distribution, and reproduction in any medium, provided the original work is properly cited. For citation use the DOI. For commercial re-use, please contact editor@rupkatha.com. 
that determine the ease or difficulty with which physical and political boundaries are crossed or constituted.

Mary Louis Pratt (1992) underlines the significant role played by travel writing in the "systematizing of nature" during the times of imperial expansion, since it was vital to the project of creating a Eurocentric "planetary consciousness, a version marked by...the descriptive apparatuses of natural history" (p.15). The long-lasting images about alien lands and customs of the 'foreign- other' created through the experiences of travel has led to the affirmation of cultural difference, and to fixing the contours of an imagined selfhood in post-imperial times as well. According to Helen Carr (2002), travel writing became "a more subjective form" in the $20^{\text {th }}$ century, "more memoir than manual, and often an alternative form of writing for novelists" (p.74). She holds the opinion that travel writing by $20^{\text {th }}$ century British novelist D.H. Lawrence Mornings in Mexico (1927) has such an "extraordinary lyricism and vitality" that it is he who writes more "about imaginary others" and "the nature of these others" than most other travel writers of his times (2002, p.84). Thus, travel writing plays a role in the shaping of what is defined by Chantal Mouffé (1998) as the 'constitutive outside' which is seminal to the creation of all collective identities (p.107) including the regional or national ones. Hence, many $19^{\text {th }}$ and $20^{\text {th }}$ century studies of tourists' tales and anthropological accounts from Europe primarily focussed on how these texts functioned as tools that gauged the alien and the foreign on a scale of the degree of modernity and development that is achieved by various societies.

\section{India and Travel Narratives}

Written by the Indian traveller and shampoo surgeon Din Muhammad in the epistolary style, The Travels of Dean Mahomet (1794) is notable as it is the first travel account by an Indian in English which celebrated the benign nature of British rule in India during the times. (Teltscher, 2003) In addition to the personal letters of voyages by Europeans who travelled to India and the narratives of expatriation that were written in English by Indians travelling to Europe in the $18^{\text {th }}$ and $19^{\text {th }}$ centuries, there were also "indigenous models of structuring experience in travel narratives found in bhasha literatures" shaped by "indigenous attitudes to travel" (Gupta, 2010, p. 31). Jayati Gupta indicates that the "closest equivalents to the western travelogue were the Persian safarnamas and the Hindu pilgrim narratives- tirthakathas or tirthamahatya written in Sanskrit and other languages derived from Sanskrit." (Gupta, 2010, p.31) Pilgrim narratives constituted a significant number of indigenous travel accounts which appeared in Sanskrit, English and various Indian bhashas in the $18^{\text {th }}$ and $19^{\text {th }}$ centuries. According to K. Suneetha Rani, "most of the early travel writings in Telugu focussed on temples and pilgrimages, and most of them were written by Brahmins." (2010, p. 215) While the construction of public roads and the increased availability of inns for travellers made pilgrimages easier in the $19^{\text {th }}$ century, the introduction of printing technology and an emerging class of educated literates may have caused an upsurge in the circulation of travel literature in that century.

\section{A Pilgrim's Chronicle from Kerala: Veera Keralavarma and His Journal}

Pilgrim narratives in Malayalam dates back to the $18^{\text {th }}$ century. Varthamanapusthakam (1778) by Paremakkal Thoma Kathanar, a chronicle of his travel to Rome can be considered as the earliest of all pilgrims' accounts that was composed in prose form by anyone from the Malayalam speaking regions of South India. Majority of the $18^{\text {th }}$ and $19^{\text {th }}$ century pilgrims' accounts by 
Keralites that described travel within the geographical territory of present-day India are composed by Brahmins, local kings and rulers. An important text of that period from Kerala which falls under the genre of travel narrative is Dharmarajavinte Rameshwaram Yatra (1784) which was composed in the kavya or verse form. It chronicles the pilgrimage undertaken by the Travancore Raja, Karthikathirunal Rama Varma to the temple town of Rameshwaram in South India.

Raja Veera Keralavarma IV, who ruled the erstwhile princely state of Kochi (Cochin) in South Western India from $1851^{-53}$ also wrote an account of his pilgrimage to Kashi (Benares) during the years 1852-53. These 'handwritten travel notes of the then Raja of Kochi' which was available in the form of a personal journal in English was not published in its original form in English. It was translated much later into Malayalam by M. Raman Namboothiri and was published as Kochirajavinte Kashiyatra (The Cochin Raja's travel to Kashi) in 2013. A close reading of the travelogue reveals to us the inquisitiveness of a Raja who liked to travel and explore new places in addition to visiting the sacred city of Benares. The narrative tells the readers that Veera Keralavarma had close associations with British administrators and it also presents us with the experiences of $a 9^{\text {th }}$ century ruler who attempted to step out of the boundaries of his kingdom with an ethnographic intent.

Many of the upper-caste Hindus in Kerala like Veera Keralavarma and his contemporaries from other parts of Southern India considered a pilgrimage to Kashi (Benares) as their ultimate goal of life and as the path to salvation. The fact that the king and his retinue started their journey from Trippunithura, the erstwhile capital of Kochi kingdom, on $6^{\text {th }}$ July, 1852 and travelled for 220 long days to reach Kashi stands proof for this. K. Suneetha Rani (2010) mentions about two early traveller's accounts by Telugus who undertook similar pilgrimages to Kashi in the $19^{\text {th }}$ century: one by Vennelakanti Subbarao Panthulu which was recorded in the form of his personal diary entries and published in 1873, and the other by Yengula Veerasamayya which was published in 1838 as Kasiyatra Charitra (pp. 215-216). The travel narratives of Keralavarma, Panthulu and Veerasamayya to the North Indian temple town in the $19^{\text {th }}$ century shows that Kashi, which is considered as the abode of Lord Shiva in popular Hindu beliefs, was a common pilgrimage destination for South Indian elites of that time. It is also notable that a pilgrimage to Kashi was often equated with death, "implicating the journey from which the travellers never came back" (Suneetha Rani, 2010, p.215). This turned out to be real in Keralavarma's case, since he died of small pox in Kashi on the $25^{\text {th }}$ of February, 1853 and his travel narrative reached Kochi along with his physical remains.

The narrative of Keralavarma's pilgrimage is structured in the form of a series of journal entries which mentions the dates and the days of the week on which the respective entries are made. In most cases, there are separate entries made for each day and on some occasions a single entry is made to include the details of incidents that happened over a few days in a row. Not only has the Raja adopted the modern form of the personal journal to narrate his journey, he has also followed the Gregorian calendar to denote months and dates which was quite unusual in Kerala since the almanac of the 'Kollam era' which starts from 824 A.D. was popularly followed in most calculations of time till the end of the $19^{\text {th }}$ century. William H. Sherman states that travel accounts in the report-form which came into being in Europe by the end of $16^{\text {th }}$ century "combined a chronological narrative of movements and events with geographic and ethnographic observations." (2002, p.30). Keralavarma's pilgrim narrative closely follows this 'report' form as it offers a chronological ordering of events and often includes a plain description of the distance covered, the destinations reached, the people whom he met and the major incidents that took 
place on a particular day or during the span of a few days' time. The narration which starts from July $6^{\text {th }}, 185^{2}$ ends with his last entry that was made on February $16^{\text {th }}, 1853$, almost 10 days before his death.

\section{The Pilgrim, The Explorer and The Ethnographer}

Apart from going on a pilgrimage to the sacred tirtha of Kashi, a spirit of adventure and the impetus to explore new places were the driving forces behind Keralavarma's journey. K.P. Padmanabha Menon, the celebrated historian of Kochi notes that Keralavarma was well versed in English and was keen about visiting all the important places in India in order to improve his 'mental and intellectual capacities' (Menon as cited in Namboothiri, 2016). The fact that the newly educated Indian elites under colonialism had begun to consider travel as a means for widening their horizons, becomes evident from Menon's remarks about Keralavarma's intent to travel. The erstwhile ruler of Kochi who reached Kashi had plans to return to his kingdom via the sacred South Indian city of Rameswaram after passing through the cities of Calcutta, Jagannath, Machilipatnam and Madras. Yet, an unfortunate turn of events led to his death in Kashi in February and he was thereafter referred to as the "Maharaja who deceased in Kashi" (Namboothiri, 2016, p.12).

Raja Veera Keralavarma had set off to Kashi on a palanquin and later continued his journey on horse-back and on horse cart at a time when transportation by railways was unknown to the people of India. Motor vehicles were also not available for public transportation in majority of the places across the subcontinent (Namboothiri, 2016). It can be inferred from his narrative that his royal retinue of about thirty people included palanquin bearers, a few servants who carried goods and essentials during the travel and a few others who occasionally cooked food for him. He was also accompanied by one Shankunny Menon, who was supposedly his tour manager and his brother-in- law whose name is not mentioned in the accounts. The reader of the travelogue is also informed about a British physician named Dr. Bingle who joined the Raja and his attendants a month later, when they reached Hosur on $7^{\text {th }}$ August, 1852 (Keralavarma Maharajavu, 2016).

The tribulations of Keralavarma's journey included passing through rough countryside roads and the challenges involved in surviving thieves who stole his money, clothes and other goods etc., in a couple of instances (Keralavarma Maharajavu, 2016). Apart from this, there are also descriptions about how he and his troop outlived the harsh weather conditions which they were not accustomed to live in. His journal entries also tell us that they often had to stay inside make-shift tents during several stormy nights and how eventually a few of his servants and his horsemen Ayyappan and Narayanan succumbed to cholera before they reached Benares (2016, pp. 51-55). Despite all these, Keralavarma completed the darshan at the temple of Vishwanatha at Kashi, took a dip in the holy river Ganga and proceeded further to Allahabad on $8^{\text {th }}$ February, 1853. Keralavarma has also recorded in his journal that he could fulfil his wish to take a dip in the confluence of the three rivers at Triveni Sangam in Allahabad after which he visited a nearby fort and a few beautiful gardens in the city of Allahabad (2016).

The chronotope of the road makes the narrative of Keralavarma's pilgrimage (tirthayatra in Sanskrit) interesting, since he meets a variety of people including British civil servants, District Collectors of the colonial government, officers in charge of laying railway lines etc. They identify him as a Raja, mingle freely with him and make arrangements for his stay in different places. He has also mentioned about his meetings with Brahmins at various places across the Deccan and the 
Eastern coast. He distributed dakshina to many of them since that was considered to be one among the duties of kings and according to Hindu religious beliefs (Keralavarma Maharajavu, 2016). On the other hand, Keralavarma has also described about many of his unpleasant encounters with some people whom he met during the journey. The manner in which he escaped from the villagers of Nellore and Balwanta who followed him howling, since he was an outsider in their land and the irritable Brahmins and sanyasis of Kasim Kotta who came behind him reciting the Vedas, begging for money, are a few among them (Keralavarma Maharajavu, 2016). As Bakhtin observes about the chronotope of the road, the road becomes "a particularly good place for random encounters.... the spatial and temporal paths of the most varied people-representatives of all social classes, estates, religions, nationalities, ages-intersect at one spatial and temporal point." (1981, p.243)

The traveller's account provides the reader with a mental map of some of the prominent places that Keralavarma visited, in the way they existed in the 1850 . This is made possible through the elucidation of geographical details like the nature of the terrain, its water bodies, flora, fauna etc. Certain ethnographic descriptions included in his journal are about the ownership of inns, the sartorial practices and livelihoods of certain groups of people, the crops that were cultivated in each region etc. The information about the spreading of epidemics like chickenpox, cholera and other contagions in certain places, the presence or absence of travellers' bungalows, prevalence of separate lodging facilities and spaces for different castes and communities etc. (Keralavarma Maharajavu, 2016). This tells us about the absence of proper healthcare facilities and public institutions in many of the caste-ridden villages and suburban spaces of $19^{\text {th }}$ century India. The details of shops, price of food grains and the names of major deities that were worshipped at particular regions also complete the illustration.

\section{Writing the 'Foreign': Writing about 'Home'}

The practice of writing about one's travel experiences and the possibilities of documenting the 'facts' that are observed about 'another' land and 'other' people have been considered as foundational for many socio-political and scientific revolutions in the modern era. De Certeau has laid out the 'spatializing operation' accomplished by travelogues through explicating their role in determining the boundaries of specific cultural fields- as ours and theirs. (1986, p. 68). Keralavarma's description of alien lands, people and their cultural practices always make lots of comparisons with his own 'country' and this can throw light on how a member of the $19^{\text {th }}$ century English educated Indian elites cognized new territorial identities within the emerging territorial unity encompassed by the colonial rule. Keralavarma's report in the first-person narrative form tells us that he opted to stay in his own tent when he was at Nellore and in a few nearby villages, since he felt that "even those who lived in the Pulaya dwellings in his country would find those "dingy inn as uninhabitable" (2016, p.30). The traveller's gaze which captures the 'cultural other' is seen to be reproducing the hierarchies and categories of 'home' in understanding the new territory, in this case. Thus, home becomes the focal point for understanding the 'foreign other' in his accounts. This is observable in his description of the alien topography as well.

Details about the presence or absence of clean water bodies is a motif that runs through the Raja's accounts. Water is an essential resource for any wayfarer or pilgrim for his/ her daily ablutions and for purposes of basic life sustenance. But Keralavarma's narrative gives primacy to the descriptions of ponds, rivers and other water bodies while portraying the topographical peculiarities of each new place that he passed by and a judgement about each place as liveable or 
uninhabitable is made on this criterion. The Raja belonged to a country and a geographical region which was full of water bodies, ranging from small ponds and rivers to the sea sides and was accustomed to elaborate rituals and ablutions using fresh water on a daily basis. The motif of water that frequently occurs in his account, in relation to each new place he visited, becomes a marker of his displacement. More than the intend to include an information about an alien land, they reminded him of the home that he was away from, apart from the occasional letters that he had received by post. Madan Sarup observes that, "On the one hand, it is interesting to leave one's homeland in order to enter the culture of others but, on the other hand, this move is undertaken only to return to oneself and one's home, to judge or laugh at one's peculiarities and limitations." (1998, p.100). Keralavarma picturises a scene that filled him with pleasure almost four months after he had set off from Kochi: it was the sight of coconut trees on a seashore, somewhere on the Eastern Coast and an anchored ship in the horizon. On this instance, he expresses his pleasure in watching the seaside which was similar to those in his homeland, after a long time. He also adds that the waves in the sea were higher and stronger than the ones in his homeland, Kochi!

José Miguel Moura Ferreira's research about colonial policy making in Goa draws upon how a new understanding of the colonial landscape was getting unified under the British rule. Emerging images of certain geographical regions as "places of unexplored wealth, whose fertile lands and rich forests could be a source of considerable income, if only they could be improved through thoughtful administration" (Moura Ferreira, 2019, p.145), turned out to be a feature of Keralavarma's narrative too. After visiting the newly built dam at Dowleswaram and listening to Engineer Major Cotton's explanation about the workings of modern machines, the Raja was impressed about the usefulness of such new technologies. Learning about the usefulness of machines that were used to break rocks and about the functioning of the train that brings the rocks, lifts which can move boats up from the water etc., Keralavarma also noted that the same technology can be beneficial in cutting down trees from Nelliampathy forests in order to bring them down to the plain lands via Chalakkudy. The new understanding of the colonial landscape treated the forest region "as a place of imaginary wealth" which possessed "natural resources like spices and timber" (Moura Ferreira, 2019, p. 150) that can be exploited. After listening to Major Cotton, the Raja was also convinced about the possibility of widening the water channel at Edathuruthy in his kingdom to make it suitable for inland travel (Keralavarma Maharajavu, 2016). Thus, it is evident from Keralavarma's account that his travel becomes a point of linkage for the various regions which fall under colonial rule, whether it be the alien one or the home geography.

The Raja who reproduces the discourses of modernization inherent to colonial policymaking can be seen as categorizing certain landscapes in the alien lands and at home as discordant while looking through the new lens of 'usability'. On November $17^{\text {th }} 1852$, when Keralavarma reached at a place named Lihineepuram which had a mossy lake, he recorded that the lake reminded him of 'Aranattukara,' a marshland in his own country, Kochi. He also added that, "Somehow, the whole place gave me an image of discord. It was difficult to move in the palanquin...Moreover, the people who crowded around the palanquin gave a tough time for me" (Keralavarma Maharajavu, 2016, p. 44). It is discernible that by creating parallels between a geographical feature at home and in the new territory, the narrator's description effectively labels what can be termed as the 'landscapes of alterity,' in both the places. 


\section{The 'Modern Self' under Colonialism}

Moving outside the familiar terrains of home culture in order to experience the previously unknown things in life with curiosity and with a critical eye was a characteristic feature of a newly evolving 'modern self under colonialism. Keralavarma has included a detailed narration of his novel experiences in Bangalore where he stayed for more than a fortnight, almost with an ethnographic precision. Visiting a theatre in Bangalore to watch a play, meeting the captain of that play on the next day, observing the drill of army officers and sepoys, watching the motor boats moving on the Ulsoor lake and appreciating the modern weaponry kept at the Mysore Raja's arsenal are a few among the exhilarating experiences listed out in the Raja's journal. He doesn't fail to record the ecstatic experience of watching the models of a steam engine and railway line that were exhibited at the Cantonment School and also expresses his astonishment in witnessing the processes of paper making, printing and binding of books at the school, the scientific advancements and public institutions that were being established through colonization. These spectacles were witnessed by Keralavarma in the presence of Dr. Bingle and in some occasions in the company of British army officials like General Mark Cubbon, Captain Aimes or Dr. Butler who often explained the use and working of these modern technologies and instruments.

Hulme and Youngs draw out the similarities between novel and travel writing in their first-person form and observes that these genres have often shared "a focus on the centrality of the self, a concern with empirical detail, and a movement through time and place which is simply sequential" (2002, p. 6). The way in which Keralavarma's narrative pronounces the unquestioning technological superiority of the West and how it indicates the Indian elites' fascination with the steam engine, the press and the railways, are analogous to the manner in which "modernity and its civilizational impulse are welcomed by Chandu Menon" (Arunima, 1997, p. 278). Published more than three decades after Keralavarma's pilgrimage, the first 'major novel' in Malayalam by O. Chandu Menon, Indulekha (1889) also stresses on "the kindness of the colonial masters and the benefits of the colonial encounter" (Arunima, 1997, p.278). While, 'westernization' through education and travel, allows Madhavan - the hero of Indulekha to discover his 'Indianness,' the Raja of Kochi who associates with the British administrators like District Collectors and army chiefs and the new literate elites from various regions across India could not have realized his own place in the wider geographical space of the nation in the making, had he been confined to the realms of the domestic. (Arunima, 1997).

Pilgrimage has also played an important role in promoting a pan Indian consciousness and in shaping a national identity in addition to extending trade relations between the culturally diverse regions of the Indian subcontinent (Gladstone, 2005). When Madhavan sets off on a "journey of discovery-almost a rite of passage-to Bombay and Calcutta, where he learnt about life outside the narrow confines of the familiar" (Arunima, 1997, p. 281), Veera Keralavarma intended to meet new people like British administrators, engineers, 'native' officials and the emerging cultural elites like him in other lands. His attempts to learn about new territories, technologies, deities and cultural practices as well as the adoption of a few life style changes that suited the new climatic conditions of the places he travelled to, resulted in the actualization of a larger geographical identity. Thus, Keralavarma's narrative shows that his journey transcended the notion of pilgrimage in the traditional sense -- neither is his journey a mere long-distance spiritual one, nor does it conform strictly to the label of non-utilitarian travel. 


\section{References}

Arunima, G. (1997). Writing culture: Of modernity and the Malayalam novel. Studies in history, 13 (2) 27129o. doi: https://doi.org/10.1177/025764309701300204

Bakhtin, M.M. (1981a). Forms of time and of the chronotope in the novel. (C. Emerson and M. Holquist, Trans.). In M. Holquist (Ed.), The Dialogic imagination: Four essays by Mikhail Bakhtin (pp. 84-258). Austin, Texas: University of Texas Press. (Original work published 1975).

Carr, H. (2002). Modernism and travel (1880-1940). In P. Hulme \& and T. Youngs (Eds.). The Cambridge companion to travel writing (pp.70-86). Cambridge, UK: Cambridge University Press.

De Certeau, M. (1986). Montaigne's "Of Cannibals": The savage "I”. (B. Massumi, Trans.). In Heterologies: Discourses on the other (pp. 67-79) Minneapolis, London: University of Minnesota Press.

Gladstone, D.L. (2005). From pilgrimage to package tour: Travel and tourism in the third world. New York, NY: Routledge Taylor \& Francis.

Gupta, J. (2010). The poetics and politics of travel writing. In S. Mandal (Ed.). Indian travel narratives (pp.26-36). Jaipur, India: Rawat Publications.

Hulme, P \& Youngs, T. (2002). Introduction. In P. Hulme \& T. Youngs (Eds.). The Cambridge companion to travel writing (pp. 1-13). Cambridge, UK: Cambridge University Press.

Keralavarma Maharajavu, V. (2016). Kochi rajavinte Kashi yatra [The Cochin king's travel to Kashi] (M. R. Namboothiri, Trans.). Calicut, India: Mathrubhumi Books.

Mouffé, Chantal. (1998). For a politics of nomadic identity. In G. Robertson, M. Mash, L. Tickner, J. Bird, B. Curtis \& T. Putnam (Eds.). Traveller's tales: Narratives of home and displacement (2nd ed. pp. 105-113). Oxon: Routledge.

Moura Ferreira, J.M. (2019). 'Rugged hills', 'dense forests' and 'backward people': Imagining landscapes in nineteenth century colonial Goa. International Journal for History, Culture and Modernity, 7, doi: http://doi.org/10.18352/hcm.550

Namboothiri, M.R. (2016). Kochirajavinte Kashiyatra. In Keralavarma Maharajavu, V. Kochi rajavinte Kashi yatra (pp.11-14) [Foreword]. Calicut, India: Mathrubhumi Books.

Pratt, M.L. (1992). Imperial eyes: Studies in travel writing and transculturation. London: Routledge.

Sarup, M. (1998). Home and identity. In G. Robertson, M. Mash, L. Tickner, J. Bird, B. Curtis \& T. Putnam (Eds.). Traveller's tales: Narratives of home and displacement (2nd ed. pp. 93-104). Oxon: Routledge.

Sherman, W.H. (2002). Stirrings and searchings (1500-1720). In P. Hulme \& T. Youngs (Eds.). The Cambridge companion to travel writing (pp. 17-36). Cambridge, UK: Cambridge University Press.

Smethurst, P. (2012). Travel writing and the natural world, 1768-1840. Basingstoke: Palgrave Macmillan.

Suneetha Rani, K. (2010). Kasiyatra Charitra: The 'first' travelogue in Telugu. In S. Mandal (Ed.). Indian travel narratives (pp. 215-227). Jaipur, India: Rawat Publications.

Teltscher, K. (2002). India/Calcutta: City of palaces and dreadful night. In P. Hulme \& T. Youngs (Eds.). The Cambridge companion to travel writing (pp. 191-206). Cambridge, UK: Cambridge University Press.

Van Den Abbeele, G. (1985). Introduction. L'Esprit Créateur,25(3), 5-7. Retrieved April 23, 2020, from www.jstor.org/stable/26284375

Dr. Niveditha Kalarikkal teaches in the Centre for Comparative Literature \& Translation Studies,Central University of Gujarat, Gandhinagar. Her areas of specialization include Translation Studies, Print Modernities and Language Politics in India. 